\title{
ANALISIS PENGARUH KOMPETENSI PROFESIONAL DAN DISIPLIN KERJA UNTUK PENINGKATAN KINERJA DOSEN
}

\author{
Arya Widiatmaja
}

Asisten Dosen PIP Semarang

\begin{abstract}
ABSTRAK
Tujuan penelitian ini untuk mengetahui pengaruh kompetensi profesional dan disiplin kerja terhadap kinerja Dosen Politeknik Ilmu Pelayaran Semarang.

Populasi penelitian ini adalah 93 Dosen dari Politeknik Ilmu Pelayaran Semarang. Analisis data menggunakan regresi linier berganda.

Berdasarkan hasil penelitian yang diketahui kompetensi profesional tidak berpengaruh positif dan signifikan terhadap kinerja dosen. Disiplin kerja berpengaruh positif dan signifikan terhadap kinerja dosen.
\end{abstract}

Keywords : kompetensi profesional, disiplin kerja, peningkatan kinerja

\section{PENDAHULUAN}

\section{A. Latar Belakang Masalah}

Dosen sebagai ujung tombak Perguruan Tinggi adalah seseorang yang berdasarkan pendidikan dan keahliannya diangkat oleh penyelenggara perguruan tinggi dengan tugas utama mengajar. Menurut Undang-Undang Nomor 14 Tahun 2005 tentang Guru dan Dosen, dosen adalah pendidik profesional dari ilmuwan denga tugas utama mentransformasikan, mengembangkan dan menyebarluaskan ilmu pengetahuan, teknologi dan seni melalui pendidikan, penelitian dan pengabdian masyarakat.

Faktor utama penyebab rendahnya mutu pendidikan adalah kondisi pengajar yaitu kualifikasinya tidak layak atau mengajar tidak sesuai bidang keahliannya. Tantangan yang terkait dengan mutu pendidik mencakup tantangan pribadi, kompetensional pribadi maupun ketrampilan pendidik dalam melaksanakan tugasnya.

Kinerja dapat dipengaruhi oleh beberapa faktor antara lain kompetensi profesional dan disiplin kerja. Penelitian mengenai pengaruh kompetensi profesional dan disiplin kerja terhadap kinerja akan dilakukan pada Dosen
Politeknik Ilmu Pelayaran Semarang. Pada saat ini Politeknik Ilmu Pelayaran Semarang sedang mengalami masalah yakni kurang maksimalnya kinerja dosen, hal ini dapat dilihat dari fenomena yang muncul, antara lain pada masalah kompetensi pada dosen antara lain kurangnya ketrampilan dosen dalam memecahkan masalah yang berorientasi pada efisiensi, produktivitas, mutu dan kepedulian terhadap lingkungan di sekitarnya, pelayaan terhadap anak didik yang kurang optimal dan kurang mengkuti perkembangan teknologi yang berkaitan dengan pendidikan pelayaran. Masalah pada kedisiplinan kerja masih adanya dosen yang kurang memperhatikan peraturan kerja (mangkir, terlambat mengajar dan tidak hadir dalam kelas). Hal tersebut mengakibatkan kinerja dosen kurang maksimal sehingga akan membawa dampak pada anak didiknya.

\section{B. Rumusan Masalah}

Berdasarkan latar belakang yang menujukkan permasalahan penelitian, maka permasalahan dalam penelitian ini adalah "Pengaruh kompetensi profesional dan disiplin kerja terhadap kinerja dosen pada Politeknik Ilmu 


\section{Arya Widiatmaja}

Pelayaran Semarang". Agar pembahasan masalah dalam penelitian lebih jelas, maka perlu adanya perumusan masalah sebagai berikut :

1. Bagaimana pengaruh kompetensi profesional terhadap kinerja Dosen Politeknik Ilmu Pelayaran Semarang?
2. Bagaimana pengaruh disiplin kerja terhadap kinerja Dosen Politeknik Ilmu Pelayaran Semarang?

Dengan kompetensi profesional, disiplin kerja yang tinggi akan dapat mendukung tercapainya kinerja yang tinggi. Berdasarkan uraian tersebut di atas maka dapat disusun kerangka teoritis sebagai berikut:

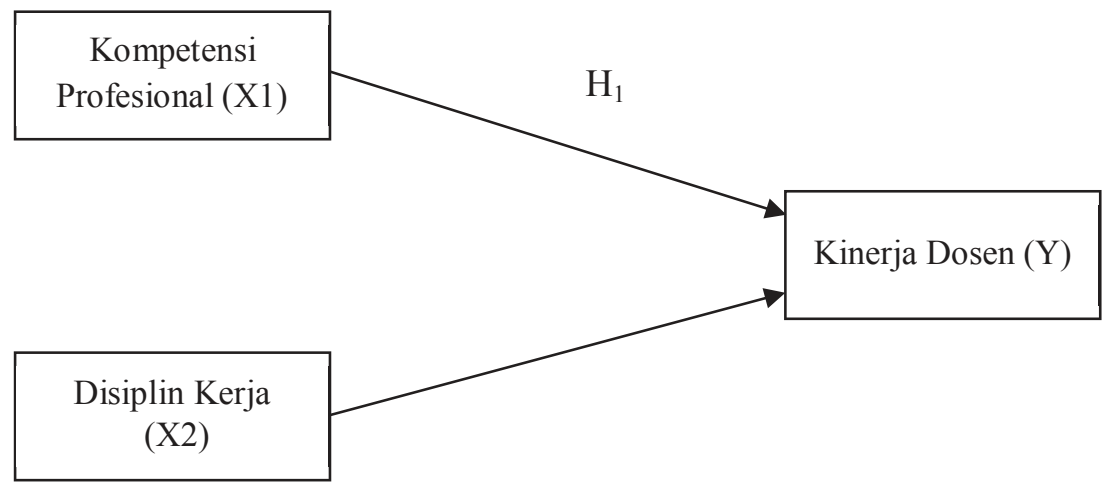

Gambar 1 : Kerangka penelitian

\section{LANDASAN TEORI}

\section{A. Kompetensi Profesional}

Richard

mengemukakan kompetensi merupakan karakteristik-karakteristik dasar seseorang yang menuntun atau menyebabkan keefektifan dan kinerja yang menonjol. Menurut Sinnott et.al (2002) kompetensi adalah alat pengkritisi dalam tugas kerja dan pergantian perencanaan. Di tingkat minimum, kompetensi berarti: a) mengenali kapabilitas, sikap dan atribut yang dibutuhkan untuk memenuhi staf saat ini dan dimasa depan sebagai prioritas organisasi dan pertukaran strategis dan b) memfokuskan pada usaha pengembangan karyawan untuk menghilangkan kesenjangan antara kapabilitas yang dibutuhkan dengan yang tersedia.

Menurut Antariksa (2007) secara umum kompetensi sendiri dapat dipahami sebagai sebuah kombinasi antara ketrampilan (skill), atribut personal, dan pengetahuan (knowledge) yang tercermin melalui perilaku kinerja (job behavior) yang dapat diamati, diukur dan dievaluasi. Dalam UndangUndang Nomor 14 Tahun 2005 tentang Guru dan Dosen kompetensi adalah seperangkat pengetahuan, keterampilan, dan perilaku yang harus dimiliki, dihayati, dan dikuasai oleh guru atau dosen dalam melaksanakan tugas keprofesionalan. Kompetensi tersebut meliputi kompetensi pedagogik, kompetensi kepribadian, kompetensi sosial dan kompetensi profesional.

Lebih lanjut Undang-Undang Nomor 14 Tahun 2005 tentang Guru dan Dosen Guru dan Dosen pasal 10 ayat 1, kompetensi profesional adalah "kemampuan penguasaan materi pelajaran secara luas dan mendalam". Surya (2003) mengemukakan kompetensi profesional adalah berbagai kemampuan yang diperlukan agar dapat mewujudkan dirinya sebagai dosen profesional. Kompetensi profesional meliputi kepakaran atau keahlian dalam 
bidangnya yaitu penguasaan bahan yang harus diajarkannya beserta metodenya, rasa tanggung jawab akan tugasnya dan rasa kebersamaan dengan sejawat dosen lainnya.

\section{B. Disiplin Kerja}

Disiplin merupakan bentuk ketaatan atau kepatuhan terhadap peraturan yang berlaku baik yang tertulis maupun tidak tertulis. Menurut Hasibuan (2003) kedisiplinan adalah kesadaran dan kesediaan seseorang mentaati semua peraturan perusahaan dan norma-norma sosial yang berlaku.

Pendapat lain mengenai disiplin kerja menurut Heidjrachman dan Husnan, (2002) mengungkapkan "Disiplin adalah setiap perseorangan dan juga kelompok yang menjamin adanya kepatuhan terhadap perintah" dan berinisiatif untuk melakukan suatu tindakan yang diperlukan seandainya tidak ada perintah". Menurut Davis (2002: 112) "Disiplin adalah tindakan manajemen untuk memberikan semangat kepada pelaksanaan standar organisasi, ini adalah pelatihan yang mengarah pada upaya membenarkan dan melibatkan pengetahuan- pengetahuan sikap dan perilaku pegawai sehingga ada kemauan pada diri pegawai untuk menuju pada kerjasama dan prestasi yang lebih baik".

Kedisiplinan di dalam prakteknya mengandung pengertian dua unsur yaitu:

1. Unsur positif, yaitu jika di dalam menjalankan tugas oknum bersangkutan ikhlas menerima tugas tersebut dan ikut bertanggung jawab atas penyelesaian dan sukses tugas itu;

2. Unsur negatif, yaitu disiplin yang mati atau tidak berjiwa, disiplin yang dipunyai oleh orang yang tidak jujur jiwanya. Bilamana suatu tugas dijalankan oleh orang seperti ini, sukar dapat berkembang dan bertanggung jawabnya tidak akan baik.

\section{Kinerja Dosen}

Hasibuan (2003) menyatakan kinerja merupakan perwujudan kerja yang dilakukan oleh karyawan yang biasanya dipakai sebagai dasar penilaian terhadap karyawan atau organisasi. Kinerja yang baik merupakan langkah untuk tercapainya tujuan organisasi. Sehingga perlu diupayakan usaha untuk meningkatkan kinerja. Tetapi hal ini tidak mudah sebab banyak faktor yang mempengaruhi tinggi rendahnya kinerja seseorang.

Depdiknas (2004), menyatakan kinerja dosen adalah kemampuan untuk melaksanakan pekerjaan atau tugas yang dimiliki dosen dalam menyelesaikan suatu pekerjaannya. Prestasi kerja atau penampilan kerja (performance). Kinerja atau performansi dapat diartikan sebagai presentasi kerja,pelaksanaan kerja, pencapaian kerja, hasil kerja atau unjuk kerja (LAN, 2004).

Untuk lebih memahami tentang kinerja dosen, berkaitan dengan kinerja dosen, ditetapkan dalam Keputusan Menteri Negara Koordinator Bidang Pengawasan Pembangunan dan Pemberdayaan Aparatur Negara No.38/KEP/MK WASPAN/8/1999, tentang Jabatan Fungsional Dosen dan Angka Kreditnya. Dalam Kepmen tersebut dinyatakan bahwa tugas pokok dosen adalah melaksanakan pendidikan dan pengajaran pada perguruan tinggi, penelitian serta pengabdian kepada masyarakat. Selanjutnya unsur utama kinerja dosen dinyatakan dalam Bab II pasal 4 ayat (2), yaitu: “... b) melaksanakan penelitian dan pengembangan serta menghasilkan karya ilmiah, karya teknologi, karya seni monumental/seni, pertunjukkan dan karya sastra.

Dari beberapa uraian tersebut, dapat dikemukakan bahwa kinerja adalah hasil kerja nyata yang dicapai seseorang dalam melaksanakan tugas yang diberikan kepadanya sesuai dengan 
Arya Widiatmaja

kriteria dan tujuan yang ditetapkan oleh organisasi.

\section{Pengembangan Hipotesis}

\section{Kompetensi profesional berpengaruh positif dan signifikan terhadap kinerja}

Dosen tidak hanya memiliki predikat profesional saja dalam menjalankan fungsinya, tetapi harus juga memiliki kompetensi yang melekat pada dirinya. Hal ini sejalan dengan Undang-Undang Nomor 14 Tahun 2005 tentang Guru dan Dosen pasal 10 bahwa pengertian kompetensi adalah seperangkat pengetahuan, ketrampilan dan prilaku yang harus dimiliki, dihayati dan dikuasai oleh dosen dalam melaksanakan tugas ke profesionalannya. Berdasarkan hal tersebut dapat dirumuskan hipotesis penelitian sebagai berikut :

H1 : Kompetensi profesional
berpengaruh positif dan
signifikan terhadap kinerja dosen
Politeknik Ilmu Pelayaran (PIP)
Semarang

2. Disiplin kerja berpengaruh positif dan signifikan terhadap kinerja

Disiplin yang baik mencerminkan besarnya tanggung jawab seseorang terhadap tugas-tugas yang diberikan kepadanya. Seseorang dikatakan mempunyai disiplin kcrja yang tinggi jika yang bcrsangkutan konsekuen, konsisten, taat asas, bertanggung jawab atas tugas yang diamanahkan kepadanya. Disiplin kerja merupakan suatu alat yang digunakan para manajer untuk berkornunikasi dengan karyawan agar mereka bersedia untuk mengubah prilaku serta sebagai suatu upaya untuk meningkatkan kesadaran dan kesediaan seseorang mentaati semua peraturan perusahaan dan normanorma sosial yang berlaku. Dengan disiplin kerja yang tinggi akan dapat membantu meningkatkan kinerja.

Penelitian mengenai pengaruh disiplin kerja terhadap kinerja pernah dilakukan oleh Sulastri (2007), Hetami (2008) dan Siwantara (2009) yang menghasilkan disiplin kerja berpengaruh positif dan signifikan terhadap kinerja. Berdasarkan hal tersebut dapat dirumuskan hipotesis penelitian sebagai berikut :

H2 : Disiplin kerja berpengaruh signifikan terhadap kinerja dosen Politeknik Ilmu Pelayaran (PIP) Semarang

\section{METODE PENELITIAN}

\section{Populasi dan Sampel Penelitian}

Populasi menurut Ferdinand (2006) adalah gabungan dari seluruh elemen yang berbentuk peristiwa, hal atau orang yang mewakili karakteristik yang serupa yang menjadi pusat perhatian seorang peneliti karena itu dipandang sebagai sebuah objek penelitian. Adapun populasi dalam penelitian ini adalah pegawai Politeknik Ilmu Pelayaran Semarang yang berjumlah 93 orang.

\section{Definisi Konsep, Operasional Dan Pengukuran Variabel}

Definisi konsep, operasional dan pengukuran variabel sebagai berikut :

a. Kompetensi professional

Kompetensi Profesional adalah "kemampuan penguasaan materi pelajaran secara luas dan mendalam" (Undang-undang No. 14 tahun 2005 tentang Guru dan Dosen), indikatornya:

1) Menguasi karakteristik masingmasing Taruna;

2) Menguasai teori belajar dan prinsip-prinsip pembelajaran;

3) Ikut mengembangkan kurikulum pendidikan;

4) Mampu mengembangkan potensi secara maksimal; 
5) Mampu menilai dan mengevaluasi;

6) Bertindak sesuai dengan norma;

7) Mampu menjadi teladan;

8) Memiliki etos kerja, tanggung jawab yang tinggi;

9) Mampu berkomunikasi dengan taruna;

10) Mampu berkomunikasi dengan sesama dosen;

11) Mampu bertindak objektif serta tidak diskriminatif;

12) Mampu mendidik di kampus.

b. Disiplin kerja $\left(\mathrm{X}_{2}\right)$

Disiplin adalah kesadaran dan kesediaan seseorang mentaati semua peraturan perusahaan dan normanorma sosial yang berlaku (Hasibuan: 2003), indikatornya:

1) Frekuensi kehadiran dalam mengajar yang baik;

2) Tepat waktu dalam pelaksanaan kuliah;

3) Menyesesuaikan materi ajar dengan SAP;

4) Merevisi buku ajar/hand out setiap tahun;

5) Melaksanakan penelitian minimal satu kali dalam setahun;

6) Melaksanakan pengabdian pada masyarakat minimal satu kali dalam setahun;

7) Berpartisipasi dalam kepanitiaan untuk kegiatan yang dilakukan oleh lembaga.

\section{c. Kinerja dosen (Y)}

Kinerja merupakan perwujudan kerja yang dilakukan oleh karyawan yang biasanya dipakai sebagai dasar penilaian terhadap karyawan atau organisasi (Hasibuan, 2003), indikatornya :

1) Menyelenggarakan kegiatan pendidikan di laboratorium, praktik keguruan dan praktek teknologi pengajaran;

2) Membimbing seminar mahasiswa;
3) Membimbing Kuliah Kerja Nyata (KKN), Praktek Kerja Nyata (PKN) dan Praktek Kerja Lapangan (PKL);

4) Membimbing tugas akhir penelitian mahasiswa;

5) Penguji pada ujian akhir;

6) Membina kegiatan mahasiswa di bidang akademik dan kemahasiswaan;

7) Mengembangkan program perkuliahan;

8) Mengembangkan bahan pengajaran;

9) Menyampaikan orasi ilmiah;

10) Membimbing dosen yang lebih rendah jabatannya;

11) Menghasilkan karya penelitian;

12) Menerjemahkan/menyadur buku ilmiah;

13) Mengedit/menyuting karya ilmiah;

14) Membuat rancangan dan karya teknologi;

15) Membuat rancangan karya seni;

16) Menduduki jabatan pimpinan dalam lembaga pemerintahan/pejabat Negara;

17) Melaksanakan pengembangan hasil pendidikan dan penelitian yang dapat dimanfaatkan oleh masyarakat;

18) Memberi latihan/penyuluhan/ penataran pada masyarakat;

19) Memberi pelayanan kepada masyarakat atau kegiatan lain yang menunjang pelaksanaan tugas umum pemerintahan dan pembangunan;

20) Membuat/menulis karya pengabdian kepada masyarakat.

\section{Jenis dan Sumber Data}

Dalam penelitian ini menggunakan data primer. Data primer merupakan data yang bersumber dari tangan pertama, data yang diambil menggunakan cara kuesioner. Kuesioner merupakan daftar pertanyaan yang dipakai sebagai pedoman untuk 


\section{Arya Widiatmaja}

mengadakan tanya jawab dengan responden mengenai pengaruh kompetensi profesional dan disiplin kerja terhadap kinerja dosen di Politeknik Ilmu Pelayaran Semarang.

\section{Tahap Pengolahan Data}

Tahap pengolahan data meliputi :

a. Editing : proses yang dilakukan setelah data terkumpul melihat apakah jawaban pada kuesioner telah lengkap.

b. Coding : proses pemberian kode tertentu terhadap aneka ragam jawaban di kuesioner untuk dikelompokkan dalam kategori yang sama.

c. Pemberian Skor : menggunakan skala Likert (J. Supranto, 1997) dengan menggunakan tujuh kategori dengan rincian $1-7$.

d. Tabulasi : pengelompokkan atas jawaban yang diteliti dan teratur kemudian dihitung dan dijumlahkan sampai terwujud dalam bentuk tabel yang berguna.

\section{Uji Instrumen Penelitian}

a. Uji Validitas

Uji validitas digunakan untuk mengukur valid tidaknya suatu indikator yang berbentuk kuesioner. Suatu kuesioner dikatakan valid jika pertanyaan mampu untuk mengungkapkan suatu yang akan diukur oleh kuesioner tersebut. Dalam penelitian ini, uji validitas menggunakan analisis faktor yaitu dengan menguji apakah butir-butir indikator atau kuesioner yang digunakan dapat mengkonfirmasikan sebuah faktor atau konstruk. Jika masing-masing pertanyaan merupakan indikator pengukur maka memiliki KMO di atas 0,5 dan signifikansi dibawah 0,05 serta memiliki nilai kriteria loading faktor pengujian sebagai berikut (Singgih Santoso, 2000) :
- Loading faktor > rule of tumb $(0,4)$ berarti valid

- Loading faktor < rule of tumb $(0,4)$ berarti tidak valid

b. Uji Reliabilitas

Suatu alat ukur instrumen disebut reliabel, jika alat tersebut dalam mengukur segala sesuatu pada waktu berlainan, menunjukkan hasil yang relatif sama. Pengukuran reliabilitas dapat dilakukan dengan koefisien Alpha Cronbach menggunakan SPSS For Windows (Singgih Santoso, 2000) dengan kriteria :

- Bila nilai alpha >0,6 maka instrumen reliabel

- Bila nilai alpha $<0,6$ maka instrumen tidak reliabel

\section{Uji Model}

Uji model data dalam penelitian ini menggunakan :

a. Analisis Regresi Berganda

Suatu analisa yang digunakan untuk mengetahui persamaan regresi yang menunjukkan persamaan antara variabel dependent dan variabel independent dengan rumus sebagai berikut :

$\mathrm{Y}=\mathrm{a}+\beta_{1} \mathrm{X}_{1}+\beta_{2} \mathrm{X}_{2}+\mathrm{e}$

Keterangan :

$\mathrm{a}=$ Konstanta

$\mathrm{Y}=$ Kinerja Pegawai

$\mathrm{X}_{1}=$ Kompetensi Profesional

$\mathrm{X}_{2}=$ Disiplin Kerja

$\beta=$ Koefisien regresi

$\mathrm{e}=$ Error

b. Koefisien determinasi

Koefisien determinasi digunakan untuk mengetahui besarnya persentase goodness of fit dari variabel independent terhadap variabel dependent (Singgih Santoso, 2000).

Rumus : $\mathrm{KD}=\mathrm{R}^{2} \times 100 \%$

Keterangan :

$\mathrm{KD}=$ Koefisien Determinasi

$\mathrm{R}^{2}=$ Koefisien Korelasi 
c. Uji Hipotesis

Uji hipotesis menggunakan uji $\mathrm{t}$ dengan model regresi linier berganda yaitu untuk mengidentifikasi pengaruh variabel independen terhadap variabel dependen dengan menggunakan SPSS (Singgih Santoso, 2000). Adapun kriteria hipotesis dengan taraf signifikan $(\alpha)$ $<0,05$. Hipotesis diterima jika $\beta>0$ dan hipotesis ditolak jika $\beta<0$.

\section{HASIL PENELITIAN DAN PEMBAHASAN}

\section{Pengujian Hipotesis}

Tabel

Hasil Hipotesis Pengaruh Kompetensi Profesional $\left(\mathrm{X}_{1}\right)$ dan Disiplin Kerja $\left(\mathrm{X}_{2}\right)$ Terhadap Kinerja Dosen $(\mathrm{Y})$

Coefficients $^{a}$

\begin{tabular}{|c|c|c|c|c|c|c|}
\hline \multirow{2}{*}{\multicolumn{2}{|c|}{ Model }} & \multicolumn{2}{|c|}{$\begin{array}{l}\text { Unstandardized } \\
\text { Coefficients }\end{array}$} & \multirow{2}{*}{$\begin{array}{c}\text { Standardized } \\
\text { Coefficients } \\
\text { Beta }\end{array}$} & \multirow[b]{2}{*}{$\mathrm{t}$} & \multirow[b]{2}{*}{ Sig. } \\
\hline & & $\mathrm{B}$ & Std. Error & & & \\
\hline \multirow[t]{3}{*}{1} & (Constant) & .000 & .059 & & .000 & 1.000 \\
\hline & Kompetensi profesional & .094 & .061 & .094 & 1.550 & .125 \\
\hline & disiplin & .743 & .063 & .743 & 11.873 & .000 \\
\hline
\end{tabular}

a. Dependent Variable: kinerja dosen

Sumber : Data primer yang diolah, 2018.

a. Pengaruh kompetensi profesional terhadap kinerja dosen

Kompetensi profesional $\left(\mathrm{X}_{1}\right)$ menghasilkan tingkat signifikan $0,125>0,05$ sehingga tidak terdapat pengaruh signifikan terhadap kinerja dosen (Y). Dengan demikian hipotesis pertama $\left(\mathrm{H}_{1}\right)$ "Kompetensi profesional berpengaruh terhadap kinerja dosen Politeknik Ilmu Pelayaran (PIP) Semarang" ditolak.

b. Pengaruh disiplin kerja terhadap kinerja dosen

Disiplin kerja $\left(\mathrm{X}_{2}\right)$ menghasilkan tingkat signifikan $0,000<0,05$ sehingga secara parsial (individu) terdapat pengaruh dan signifikan terhadap kinerja dosen (Y). Dengan demikian hipotesis ketiga $\left(\mathrm{H}_{2}\right)$ "Disiplin kerja berpengaruh terhadap kinerja dosen Politeknik Ilmu Pelayaran (PIP) Semarang" dapat diterima.

\section{Pembahasan}

Penelitian yang dilakukan untuk mengetahui pengaruh kompetensi profesional, motivasi kerja dan disiplin kerja terhadap kinerja dosen Politeknik Ilmu Pelayaran Semarang adalah sebagai berikut :

a. Pengaruh kompetensi profesional terhadap kinerja dosen

Kompetensi profesional $\left(\mathrm{X}_{1}\right)$ menghasilkan tingkat signifikan 0,125 $>0,05$ sehingga secara parsial (individu) tidak terdapat pengaruh signifikan terhadap kinerja dosen (Y). Dengan demikian hipotesis pertama $\left(\mathrm{H}_{1}\right) \quad$ "Kompetensi profesional berpengaruh terhadap kinerja dosen Politeknik Ilmu Pelayaran (PIP) Semarang" ditolak. Penelitian ini sama dengan penelitian yang dilakukan oleh Indrawati (2006) yang menghasilkan kompetensi profesional tidak berpengaruh positif dan signifikan terhadap kinerja. Sedangkan penelitian 
Arya Widiatmaja

yang berlawanan dilakukan oleh Hetami (2008) dan Siwantara (2009) yang menghasilkan kompetensi profesional berpengaruh dan signifikan terhadap kinerja.

Dengan kompetensi profesional dosen yang tinggi akan dapat membantu meningkatkan kinerja dosen, tetapi pada penelitian ini menunjukkan kompetensi profesional dosen Politeknik Ilmu Pelayaran (PIP) Semarang tidak mempengaruhi kinerja dosen. Hal ini menunjukkan dengan kompetensi profesional yang tinggi dosen Politeknik Ilmu Pelayaran (PIP) Semarang belum tentu mempunyai kinerja yang tinggi pula.

b. Pengaruh disiplin kerja terhadap kinerja dosen

Disiplin kerja $\left(\mathrm{X}_{2}\right)$ menghasilkan tingkat signifikan $0,000<0,05$ sehingga terdapat pengaruh dan signifikan terhadap kinerja dosen $(\mathrm{Y})$. Dengan demikian hipotesis ketiga $\left(\mathrm{H}_{3}\right)$ "Disiplin kerja berpengaruh terhadap kinerja dosen Politeknik Ilmu Pelayaran (PIP) Semarang "diterima". Penelitian ini sesuai dengan penelitian yang dilakukan oleh Sulastri (2007), Hetami (2008) dan Siwantara (2009) yang menghasilkan disiplin kerja berpengaruh positif dan signifikan terhadap kinerja.

Disiplin yang baik mencerminkan besarnya tanggung jawab seseorang terhadap tugas-tugas yang diberikan kepadanya. Seseorang dikatakan mempunyai disiplin kcrja yang tinggi jika yang bcrsangkutan konsekuen, konsisten, taat asas, bertanggung jawab atas tugas yang diamanahkan kepadanya. Disiplin kerja merupakan suatu alat yang digunakan para manajer untuk berkornunikasi dengan karyawan agar mereka bersedia untuk mengubah perilaku serta sebagai suatu upaya untuk meningkatkan kesadaran dan kesediaan seseorang mentaati semua peraturan perusahaan dan norma-norma sosial yang berlaku. Dengan disiplin kerja yang tinggi akan dapat membantu meningkatkan kinerja.

\section{PENUTUP}

\section{Kesimpulan}

Berdasarkan analisis data mengenai pengaruh kompetensi profesional dan disiplin kerja terhadap kinerja dosen Politeknik Ilmu Pelayaran Semarang dapat diambil kesimpulan sebagai berikut :

a. Kompetensi profesional tidak berpengaruh positif dan signifikan terhadap kinerja dosen;

b. Disiplin kerja berpengaruh positif dan signifikan terhadap kinerja dosen.

\section{Keterbatasan Penelitian}

Keterbatasan yang terdapat pada penelitian ini antara lain :

a. Waktu penelitian yang terbatas sehingga penelitian hanya terbatas pada Dosen Politeknik Ilmu Pelayaran;

b. Sampel penelitian hanya terbatas pada Dosen Politeknik Ilmu Pelayaran Semarang masih ada pegawai lain yang belum diikutsertakan sebagai sampel.

\section{Saran}

Berdasarkan dari hasil penelitian mengenai pengaruh kompetensi profesional dan disiplin terhadap kinerja dosen Politeknik Ilmu Pelayaran Semarang, maka dapat dikemukakan beberapa saran :

a. Variabel disiplin kerja mempunyai pengaruh terbesar terhadap kinerja dosen Politeknik Ilmu Pelayaran Semarang, oleh sebab itu pihak Politeknik Ilmu Pelayaran Semarang perlu meningkatkan lagi kedisiplinan dosen dengan memperbaiki indikator 
dilihat dari jawaban responden yang masih rendah;

b. Memasukkan variabel-variabel lain yang mempengaruhi kinerja dosen selain kedua variabel di atas seperti kompensasi, kepemimpinan dan lingkungan kerja;

c. Pengambilan sampel dapat diperluas lagi tidak hanya dosen yang ada di Politeknik Ilmu Pelayaran Semarang.

\section{Implikasi}

Sebagai suatu penelitian yang telah dilakukan di lingkungan pendidikan maka kesimpulan yang ditarik tentu mempunyai implikasi dalam bidang pendidikan dan juga penelitianpenelitian selanjutnya, sehubungan dengan hal tersebut maka implikasinya adalah sebagai berikut :

a. Selama ini masalah Kinerja Dosen kurang mendapat perhatian yang serius baik dari pihak lembaga maupun dari pihak Dosen. Maka dalam mengatasi masalah tersebut, diperlukan adanya usaha dan upaya dari pihak lembaga dan dari pihak pimpinan, dalam rangka meningkatkan Kinerja Dosen dengan cara mengadakan perbaikan pada variabel kompetensi perofesional dan disiplin yang dijalankan di Politeknik Ilmu Pelayaran Semarang. Dengan mengadakan perbaikan pada variabel tersebut diharapkan Kinerja Dosen akan semakin meningkat;

b. Aspek-aspek yang diteliti dan penelitian ini dilakukan dengan pendekatan kuantitatif, maka untuk lebih mendalam faktor-faktor apa saja yang turut berpengaruh terhadap Kinerja Dosen tersebut. Perlu kiranya dilakukan penelitian lebih lanjut dengan pendekatan kualitatif.

\section{Rekomendasi penelitian yang akan datang}

Berdasarkan dari hasil penelitian mengenai pengaruh kompetensi profesional dan disiplin kerja terhadap kinerja dosen Politeknik Ilmu Pelayaran Semarang, maka dapat ditindak lanjuti oleh peneliti yang aakan datang :

a. Memasukkan variabel-variabel lain yang mempengaruhi kinerja pegawai selain kedua variabel di atas seperti gaya kepemimpinan, pomosi jabatan dan lingkungan kerja;

b. Pengambilan sampel dapat diperluas lagi tidak hanya pegawai yang ada di Politeknik Ilmu Pelayaran Semarang.

\section{DAFTAR PUSTAKA}

Hetami, Adietya Arie. 2009. Pengaruh Motivasi, Kemampuan dan Disiplin Terhadap Kinerja Karyawan Pada Sebuah Persero Asuransi, Jurnal Ekonomi dan Bisnis, Vol. 6 No. 2, September 2009, ISSN

Tjahjono, Binawan Nur dan Tri Gunarsih. 2007. Pengaruh Motivasi Kerja dan Budaya Organisasi Terhadap Kinerja Pegawai di Lingkungan Dinas Bina Marga Propinsi Jawa Tengah, Jurnal Manajemen SDM, Vol. 4 Edisi 2 tahun 2007

Boyatzis. 2008. Manajemen Personalia Modern. Edisi Ketiga. Jakarta : Erlangga

Buhler. 2004. Human Resource Management. Sixth Edition. USA : Allyn \& Bacon Ic

Departemen Pendidikan Nasional. 2004. Pengembangan Perangkat Penilaian Kinerja Guru, Ditjen Dikti, Bagian Proyek P2RK, Jakarta

Sudjana, Dharma. 2005. Dasar-dasar Proses Pembelajaran. Bandung : Sinar Baru

Suparno, Edi. 2005. Pengaruh Kompetensi, Motivasi Kerja dan Kecerdasan Emosional Guru Terhadap Kinerja Guru di SMP N Se Rayon Barat Kab. Sragen, Jurnal Manajemen Pendidikan Vol. 2 Edisi 4 tahun 2005 
Arya Widiatmaja

Malayu, Hasibuan, S. P. 2003. Manajemen Sumber Daya Manusia. Jakarta : PT. Bumi Aksara

Siwantara, I Wayan. 2009. Pengaruh Kompetensi Profesional dan Motivasi Kerja Serta Iklim Organisasi Terhadap Disiplin Kerja dan Kinerja Dosen Politeknik Negeri Bali, Ragam Vol. 9 No. 2 Agustus 2009, 224 - 241

Ghozali, Imam. 2006. Aplikasi Analisis Multivariate dengan Program SPSS. Semarang : Badan Penerbit Universitas Diponegoro

Jonathan, et al. 2000. The Effects of Profesional Development on Science Teaching Practices and Classroom Culture, Journal of Reasearch in Science Teaching, Vol. 37 No. 9. pp. $963-980$

Mangkunegara, Anwar Prabu. 2001. Perilaku dan Budaya Organisasi. Bandung : Refika Aditama

Maslow, Abraham H. 1954. Motivation And Personality. New York : Harper \& Row Publiser

Messa Media Gusti. 2012. Pengaruh Kedisiplinan, Motivasi Kerja dan Persepsi Guru Tentang Kepemimpinan Kepala Sekolah Terhadap Kinerja Guru SMKN 1 Purworejo Pasca Sertifikasi, Jurnal Penelitian Universitas Negeri Yogyakarta

Mulyasa. 2004. Kurikulum Berbasis Kompetesi, Konsep, Karakteristik dan Implementasi. Bandung : Remaja Rosdakarya

Ololube . 2006. Teachers Job Satisfaction and Motivation for School Effectiveness : An Assessment University of Helsinki Firlandia, International Journal

Boyatzis, Richard E. 2008. Kompetensi Diri. Jakarta : PT. Handal Niaga Pustaka
Robbins, Stephen P. 2006 Organization Behavior. New Jersey : Prentice Hall International

Santrock. 2001. Slf Afficacy. Jakarta : Ghalia Indonesia

Sinnott, et.al, 2002, Manajemen Sumber Daya Manusia. Jakarta : Bima Aksara

Hadi, Sutrisno. 2001. Metode Penelitian Riset. Yogyakarta : Yayasan Penerbit Fakultas Biologi UGM

Sulastri, Tuti. 2007. Hubungan Motivasi Berprestasi dan Disiplin Dengan Kinerja Dosen, Jurnal Optimal, Vol. 1 No. 1 Maret 2007

Undang-undang Republik Indonesia Nomor. 14 Tahun 2005 tentang Guru dan Dosen. Jakarta : Tamita Utama

Indrawati, Yuliani. 2006. Faktor-faktor Yang Mempengaruhi Kinerja Guru Matematika Dalam Pelaksanaan Kurikulum Berbasis Kompetensi (KBK) Pada Sekolah Menengah Atas Kota Pemalang, Jurnal Manajemen dan Bisnis Sriwijaya, Vol. 4 No. 7 Juni 2006 